\title{
Assessment of genetic fidelity of Fritillaria dagana (Liliaceae) regenerated plants using ISSR markers
}

\author{
Dinara S. Muraseva ${ }^{1, *}$, Elena $V$. Kobozeva $^{1,2}$, and Tatyana I. Novikova ${ }^{1}$ \\ ${ }^{1}$ Central Siberian Botanical Garden, Siberian Branch RAS, 630090 Novosibirsk, Russia \\ ${ }^{2}$ National Research Tomsk State University, 634050, Tomsk, Lenina pr., 36
}

\begin{abstract}
ISSR analysis of Fritillaria dagana, endangered ornamental geophyte from the Sayan Mountains, regenerated through direct gemmogenesis from bulb scale tissue was performed. More informative electrophoresis profile with clear and distinct bands was obtained at amplification with $(\mathrm{CAC})_{3} \mathrm{GC}$ primer at $56{ }^{\circ} \mathrm{C}$ annealing. The genetic fidelity of $F$.dagana regenerants to maternal plants was confirmed.
\end{abstract}

\section{Introduction}

The genus Fritillaria L. (Liliaceae) presents ephemeral bulbous plants and comprises more than 150 species distributed within the Northern Hemisphere with a pronounced center of diversity in southwestern and Himalayan Asia [1]. Twelve of fritillaria species occur in the territory of Russia, therewith five of them are listed in the Red Data Book of the Russian Federation [2] with the status of rare species. Since many natural species of the genus Fritillaria are endangered due to irregular gathering the bulbs and flowering shoots, it is necessary to find new effective approaches for their conservation. Previously we developed the protocol of clonal micropropagation of local endemic Fritillaria sonnikovae Schaulo and A. Erst from West Sayan for creation of in vitro Fritillaria collection [3].

Fritillaria dagana Turcz. ex Trautv. is an endemic species listed in the Red Data Book of the Russian Federation [2] with the status of a rare species (3a) which occurs in certain areas of Siberia, East Sayan and Southern Baikal. An efficient micropropagation protocol of $F$. dagana was developed for the first time [4].

Although clonal propagation should generate plantlets identical to the mother plants, studies have shown that genetic and epigenetic changes called somaclonal variations may occur due to callus formation, use of growth regulators and long period of cultivation. Therefore the risk of somaclonal variation appearance should be assess by using various methods including morphological, biochemical and molecular ones [5, 6]. Molecular methods represent an effective tool for detection of regenerant genetic variability, which is explained by a higher level of DNA changes in comparison with morphological polymorphism. One of the effective methods required in this study is the ISSR analysis (Inter Simple Sequence Repeats). This method is easy to use, low-cost, high reliable,

* Corresponding author: dsmuraseva@csbg.nsc.ru 
reproducible, and methodologically less demanding compared to other dominant markers $[7,8,9]$. To date, there is a large number of studies devoted to the detection of somaclonal variation using the ISSR analysis [10, 11,8].

The present study was undertaken to assess somaclonal variation with the use of ISSR markers in $F$. dagana regenerants obtained through direct gemogenesis from bulb scale tissue.

\section{Material and methods}

The aseptic scales were cut into the segments of $5 \times 5 \mathrm{~mm}$ size and used as primary explants. Scale segments (for 4-5 pcs.) were placed by cut-surface down onto induction medium. The cultivation was carried out on solidified $B_{5}$ medium [12] supplemented with 5.0- $\mu \mathrm{M}$ 6-benzylaminopurine (BAP) and 2.0- $\mu \mathrm{M} \alpha$-naphthalene acetic acid (NAA). Microclones of $F$. dagana obtaned through direct regeneration from bulb scale tissue were used for genetic analysis. In vitro-raised microbulbs (regenerants) and maternal bulb scale segments were analysed.

DNA was extracted from silica dried bulblets using a Food and Raw materials extraction DNA Kit (BioSilica, Russia) and purified on columns following the manufacturer's protocol. Purity and concentration of the extracted DNA were evaluated using BioSpectrometer kinetic (Eppendorf, Germany) spectrophotometer with $\mu$ Cuvette G1.0 (Eppendorf, Germany) microcuvette.

Fifteen ISSR primers were initially screened: $(\mathrm{CA})_{6} \mathrm{GT},(\mathrm{CA})_{6} \mathrm{AG},(\mathrm{CT})_{8} \mathrm{TG},(\mathrm{AG})_{8} \mathrm{YC}$, $(\mathrm{CAC})_{3} \mathrm{GC},(\mathrm{CTC})_{3} \mathrm{GC},(\mathrm{AC})_{8} \mathrm{CG},(\mathrm{AC})_{8} \mathrm{YG},(\mathrm{GA})_{8} \mathrm{YC},(\mathrm{CT})_{8} \mathrm{AC},(\mathrm{CA})_{6} \mathrm{AC},(\mathrm{CA})_{6} \mathrm{GG}$, $(\mathrm{CA})_{6} \mathrm{RG},(\mathrm{GAA})_{6},(\mathrm{GACAC})_{4}$. PCR was performed on $\mathrm{C} 1000$ Thermal Cycler (BioRad Laboratories, USA). The reaction mixture of $15.0 \square \mathrm{L}$ contained $2.7 \square \mathrm{M} \mathrm{MgCl}_{2}, 1.25 \square \mathrm{M}$ primer, $0.4 \square \mathrm{M}$ dNTP, $1 \times$ PCR buffer, 1.5 of Taq polymerase (Medigen, Russia) and 5.0 ng of template DNA. The amplification reaction consisted of an initial denaturation step at $94{ }^{\circ} \mathrm{C}$ for $1.30 \mathrm{~min}$, followed by 35 cycles of $40 \mathrm{~s}$ denaturation at $94{ }^{\circ} \mathrm{C}, 45 \mathrm{~s}$ annealing at $51{ }^{\circ} \mathrm{C}$ and $56{ }^{\circ} \mathrm{C}, 1.30$ min extension at $72{ }^{\circ} \mathrm{C}$ with a final extension of $72{ }^{\circ} \mathrm{C}$ for $5 \mathrm{~min}$. The amplified products were separated by gel electrophoresis on $1.5 \%$ agarose gels in $1 \times \mathrm{TBE}$ buffer and stained with SYBR-Green (Medigen, Russia). The sizes of the amplification products were estimated with a DNA ladder (Medigen, Russia). DNA fragments were visualized using Gel Doc XR+ and analyzed with Image Lab Software (BioRad Laboratories, USA).

\section{Results and discussion}

The first changes on the scale surface - the overgrowth of explant tissue - were observed 55-56 days after inoculation on nutrient media. No formation of callus on the in vitro culture initiation stage was noted, bulblet regeneration occurred through direct gemmogenesis. The emergence of buds was occurred on the undamaged part of bulb scale protruding above the surface of the medium, but growth of them - close to the wound surface. The frequency of the microshoot regeneration achieved $66 \%$ and $3.6 \pm 0.4$ bulblets were formed, on the average, per one explant. Adventitious bulblets obtained from direct regeneration were separated from the primary explant and used for DNA extraction.

At screening of fifteen ISSR primers, only six were effective (Table). At the stage of the preliminary experiment we tested two annealing temperatures $-51{ }^{\circ} \mathrm{C}$ and $56{ }^{\circ} \mathrm{C}$. As a result of DNA-PCR amplification, 5-17 bands ranging in size from $200 \mathrm{bp}$ to $2500 \mathrm{bp}$ depending on the annealing temperature were obtained. 
Table The general characteristics of the ISSR primers used in the somaclonal variation tests of Fritillaria dagana

\begin{tabular}{|l|c|c|c|}
\hline \multirow{2}{*}{$\begin{array}{c}\text { Primer sequence } \\
\left(5^{\prime}-3^{\prime}\right)\end{array}$} & \multicolumn{2}{|c|}{$\begin{array}{c}\text { Number of bands, annealing } \\
\text { temperature }\left({ }^{\circ} \mathrm{C}\right)\end{array}$} & \multirow{2}{*}{ Band size, bp } \\
\cline { 2 - 3 } & $51^{\circ} \mathrm{C}$ & $56^{\circ} \mathrm{C}$ & \\
\hline$(\mathrm{CT})_{8} \mathrm{TG}$ & 8 & 9 & $500-1500$ \\
\hline$(\mathrm{CAC})_{3} \mathrm{GC}$ & 14 & 15 & $200-2500$ \\
\hline$(\mathrm{CTC})_{3} \mathrm{GC}$ & 14 & 17 & $200-2300$ \\
\hline$(\mathrm{CA})_{6} \mathrm{GT}$ & 12 & 15 & $200-2500$ \\
\hline$(\mathrm{CA})_{6} \mathrm{AG}$ & 8 & 14 & $250-2000$ \\
\hline$(\mathrm{AG})_{8} \mathrm{YC}^{*}$ & 8 & 14 & $450-2000$ \\
\hline
\end{tabular}

$* \mathrm{Y}=\mathrm{C}$ or $\mathrm{T}$

Low differentiation of the amplification products was established at $51{ }^{\circ} \mathrm{C}$ of annealing for $(\mathrm{CT})_{8} \mathrm{TG},(\mathrm{CA})_{6} \mathrm{GT},(\mathrm{CA})_{6} \mathrm{AG}$ and $(\mathrm{AG})_{8} \mathrm{YC}$ primers, what complicated the analyze of the amplification profile (Fig. 1 a). Unclear bands were observed with $(\mathrm{CA})_{6} \mathrm{AG}$ and $(\mathrm{AG})_{8} \mathrm{YC}$ at $56{ }^{\circ} \mathrm{C}$ annealing. The maximum number (17) of bands was obtained using $(\mathrm{CTC})_{3}$ GC. More informative amplification profiles with clear and distinct bands were at PCR with (CAC) ${ }_{3} \mathrm{GC}$ at $56{ }^{\circ} \mathrm{C}$ of annealing (Fig. $1 \mathrm{~b}$ ).
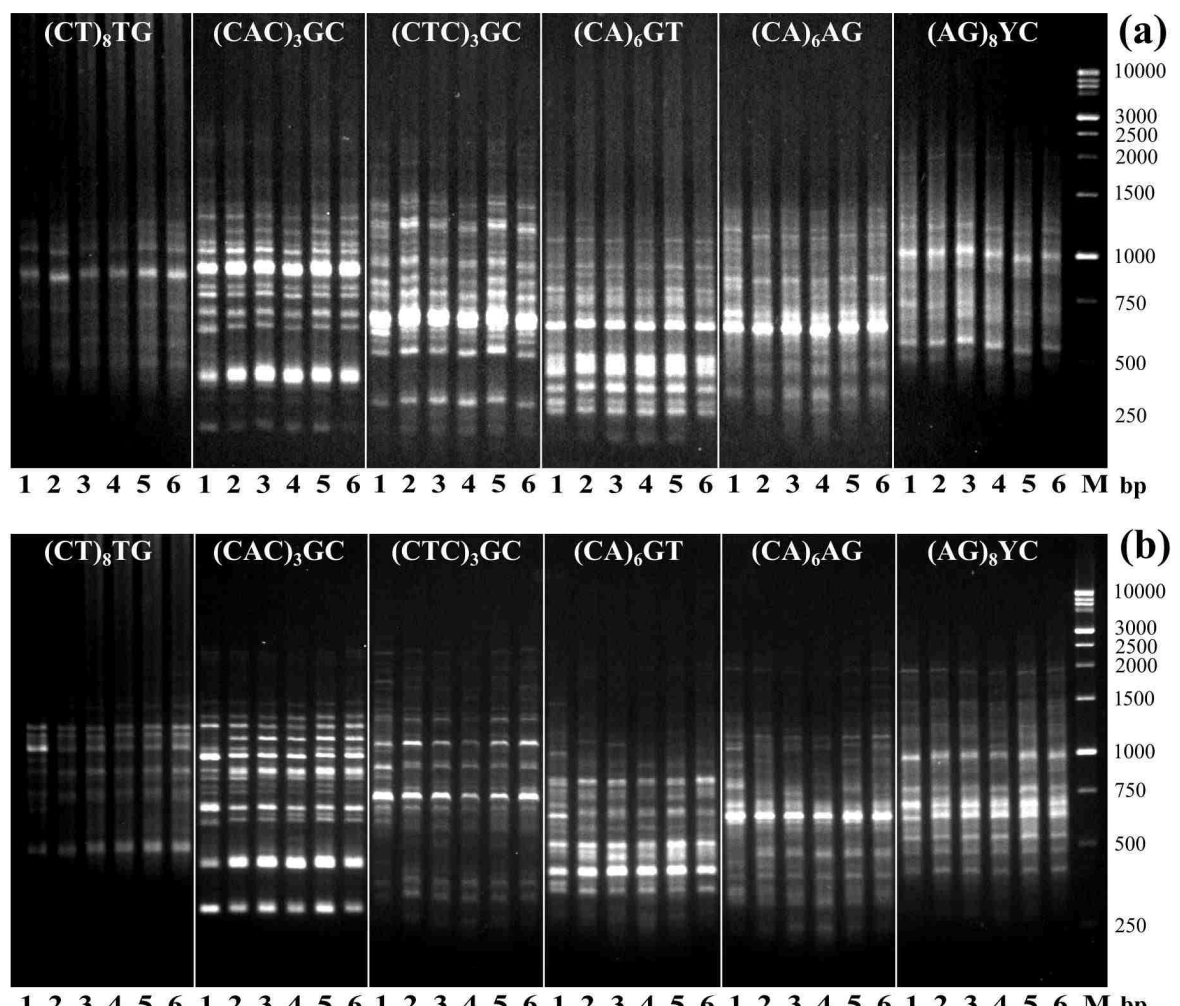

Fig. 1. PCR amplification profiles obtained with ISSR markers of the first generation of Fritillaria dagana regenerated plants (2-6 treks) in comparison with the maternal plant (1 trek); primers:

$(\mathrm{CT})_{8} \mathrm{TG},(\mathrm{CAC})_{3} \mathrm{GC},(\mathrm{CTC})_{3} \mathrm{GC},(\mathrm{CA})_{6} \mathrm{GT},(\mathrm{CA})_{6} \mathrm{AG},(\mathrm{AG})_{8} \mathrm{YC}$, annealing temperature: $\mathbf{a}-51^{\circ} \mathrm{C}$, b $-56{ }^{\circ} \mathrm{C}, \mathrm{M}-\mathrm{a}$ molecular marker; $\mathrm{B}_{5}$ nutrient medium supplemented with BAP $5.0 \mu \mathrm{M}$ and NAA $2.0 \mu \mathrm{M}$ 
Generally, the banding profiles from micropropagated plants (2-6 treks) were monomorphic and similar to those of the mother plants (1 trek). In some cases, the differences between the patterns were observed because of different degree of the amplification products during PCR, wich was clarified and checked by repeatability of PCR. As a result, the genetic fidelity of the regenerants to the maternal plant was revealed.

Genetic marking technologies are widely applied methods for monitoring of genetic fidelity of regenerated plants. The diagnostic capabilities of the ISSR markers used by us were successfully illustrated by numerous studies of somaclonal variation in different plant species $[13,14]$.

In our study, we relied on the work based on assessment of genetic diversity of $F$. thunbergii Miq. [15] and F. imperialis L. [16] nature populations by ISSR analysis. We used two primers - $(\mathrm{AG})_{8} \mathrm{YC}$ and $(\mathrm{GAA})_{6}$ which were offered in the publications. However, in the work with $F$. dagana regenerants the primers didn't show the expected polymorphism and were not considered in further analysis of somaclonal variation. Perhaps the reason is that these species belong to different subgenera - Fritillaria, Petilium and Liliorhiza, respectively. Previously we used the ISSR markers for identifying somaclonal variation of F. sonnikovae Schaulo et A. Erst after in vitro slow-growth storage [3]. It was established that the genetic variation process of regenerated plant formed through direct organogenesis did not occur at the first passage following in vitro storage for twelve months. We applied the same primer set and achieved the informative PCR amplification profile. The similarity of the effectivness of the ISSR primers can be explained by the position of this plants in one intraspecies group - subgenera Liliorhiza.

Thus, the results allow concluding that there is no somaclonal variation of $F$. dagana regenerated plants obtained within the direct gemmogenesis from bulb scale explant tissue. However, these results should be considered preliminary because the ISSR analysis for $F$. dagana was applied for the first time. In future it is planned to optimize the DNA extraction protocol, PCR program, and to carry out a statistical data processing for a large number of primers wich will ensure reliability of the results.

The reported study was funded by RFBR according to research project № 18-34-00164\18.

In our study, material from the collection of the Central Siberian Botanical Garden SB RAS USU_440534 "Collection of living plants indoors and outdoors" was used.

\section{References}

1. N. Rønsted, S. Law, H. Thornton, M.F. Fay, M.W. Chase Mol. Phylogen. Evol. 35, 509-527 (2005)

2. L.V. Bardunov, V.S. Novikov, Red Book of Russian Federation (plants and fungi) (KMK Scientifc Press Ltd., Moscow, 2008)

3. D.S. Muraseva, N.S. Zvyagina, T.I. Novikova, O.V. Dorogina, Vavilov J. Gen. Breed. 21, 554-560 (2017)

4. A.A. Erst, A.S. Erst, D.N. Shaulo, D.S. Kulkhanova, Flora Asian Rus. 1, 64-70 (2014)

5. V. Rani, A. Parida, S. Raina Plant Cell. Rep. 14, 459-462 (1995)

6. O.M. Bublyk, I.O. Andreev, K.V. Spiridonova, V.A. Kunakh Biol. Plant. 56, 459-462 (2012)

7. M.W. Bairu, C.W. Fennell, J. Van Staden, Sci. Hortic. 108, 147-173 (2006)

8. X. Liu, G. Yang, In Vitro Cell. Dev. Biol. - Plant. 48, 172-179 (2012) 
9. W. Al Khateeb, E. Bahar, J. Lahham, D. Schroeder, E. Hussein, Physiol. Mol. Biol. Plants. 19, 157-164 (2013)

10. S.S. Das Bhowmik, A. Basu, L. Sahoo, J. Crop Sci. Biotech. 19, 157-165 (2016)

11. S. Saha, S. Adhikari, T. Dey, P. Ghosh, Meta Gene 7, 7-15 (2016)

12. O.L. Gamborg, D.E. Eveleigh, Can. J. Biochem. 46, 417-421 (1968)

13. Z.-F. Yin, B. Zhao, W.-L. Bi, L. Chen, Q.C. Wang, In Vitro Cell. Dev. Biol.-Plant 49, 333-342 (2013)

14. M.A. Ramírez-Mosqueda, L.G. Iglesias-Andreu, Plant Cell Tiss. Organ. Cult. 123, 657-664 (2015)

15. S. Li, K. Hu, J.Guo, X. Yang, Y. Zhu, Z. Cheng, Biochem. Syst. Ecol. 39, 725-731 (2011)

16. S. Badfar-Chaleshtori, B. Shiran, M. Kohgard, H. Mommeni, A. Hafizi, M. Khodambashi, N. Mirakhorli, K. Sorkheh, Biochem. Syst. Ecol. 42, 35-48 (2012) 